\title{
ALASAN-ALASAN DIBALIK DIBATALKANNYA UNDANG- UNDANG NOMOR 27 TAHUN 2004 TENTANG KOMISI KEBENARAN DAN REKONSILIASI DI INDONESIA
}

\author{
Mochammad Tanzil Multazam \\ Universitas Muhammadiyah Sidoarjo
}

\section{Kasus Posisi}

Wacana Komisi Kebenaran dan Rekonsiliasi (KKR) hangat diperbincangkan sejak dimulainya gaung reformasi pada akhir tahun 1998. Keinginan kuat masyarakat untuk segera lepas dari tekanan pelanggaran HAM khususnya pelanggaran HAM berat yang terjadi pada masa orde baru, menjadi pemicu meningkatnya pemikiran-pemikiran akan perlindungan HAM.

Hal itulah yang kemudian mendorong pemerintah untuk segera mewujudkan KKR, menyusul keputusan Presiden Soeharto untuk mengundurkan diri di tahun 1998. Pemerintah transisi pimpinan Gus Dur, dan penerusnya Megawati, walaupun mungkin tidak berkeberatan dengan gagasan tentang KKR ini, pada dasarnya lebih banyak mengambil posisi pasif, meski kemudian tidak dapat dipungkiri bahwa pada masa pemerintahan Megawati Undang-Undang KKR yang dibatalkan itu ditetapkan, tetapi hal itu lebih dikarenakan dorongan dari elemen masyarakat melalui beberapa LSM.

Pembentukannya juga merupakan amanat Pasal 47 ayat (2) Undang-Undang Nomor 26 Tahun 2000 tentang Pengadilan Hak Asasi Manusia. Selain amanat tersebut, pembentukan Komisi Kebenaran dan Rekonsiliasi ini juga didasarkan pada Ketetapan Majelis Permusyawaratan Rakyat Nomor V/MPR/2000 tentang Pemantapan Persatuaan dan Kesatuan Nasional yang menugaskan untuk membentuk Komisi Kebenaran dan Rekonsiliasi Nasional sebagai lembaga ekstra yudisial yang jumlah anggota dan kriterianya ditetapkan dalam undang-undang.

Dari beragamnya alasan tersebut, sungguh disayangkan jika kemudian UndangUndang tersebut pada bulan Desember tahun 2006 dinyatakan tidak lagi memiliki kekuatan yang mengikat atau dibatalkan oleh putusan majelis hakim Mahkamah Konstitusi. Majelis hakim menilai undang-undang tersebut bertentangan dengan UUD 1945 Amandemen ke IV, tidak memiliki kewenangan yang jelas karena tidak memiliki daya ikat dan tidak memiliki konsistensi hukum sehingga tidak memiliki kepastian hukum. 


\section{Ketentuan Undang-Undang}

Dalam Pasal 28 Undang-Undang Dasar Republik Indonesia Tahun 1945 Amandemen Ke IV disebutkan bahwa setiap orang berhak atas Hak untuk tidak disiksa, mendapat perlindungan hukum atas hak asasinya, jaminan hukum, dan kepastian hukum.

\section{Pertanyaan Hukum}

Apakah yang melatar belakangi Mahkamah Kontitusi dalam menetapkan putusan pembatalan terhadap Undang-undang Nomor 27 Tahun 2004 tentang Komisi Kebenaran Dan Rekonsiliasi ?

\section{Analisis}

A. Dasar Hukum

1) Undang-Undang Dasar Republik Indonesia Tahun 1945 Amandemen Ke IV

2) Undang-Undang Nomor 26 Tahun 2000 tentang Pengadilan HAM

3) Undang-Undang Nomor 11 Tahun 2006 tentang Pemerintahan Aceh

4) Putusan Mahkamah Konstitusi Nomor 20 tahun 2006 tentang pengujian terhadap Undang-Undang Nomor 27 Tahun 2004

5) Konvensi Internasional tentang Hak-Hak Sipil dan Politik (International Convenat of Civilian And Political Rights) ${ }^{1}$

B. Pengertian-pengertian

1. Menurut Wikipedia Indonesia, yang dimaksud dengan Komisi Kebenaran Dan Rekonsiliasi adalah sebuah komisi yang ditugasi untuk menemukan dan mengungkapkan pelanggaran-pelanggaran yang dilakukan di masa lampau oleh suatu pemerintahan, dengan harapan menyelesaikan konflik yang tertinggal dari masa lalu.

2. Menurut Undang-Undang No.27 Tahun 2004, yang dimaksud dengan Komisi Kebenaran Dan Rekonsiliasi adalah lembaga independen yang

\footnotetext{
${ }^{1}$ Software Pencari Perundang-undangan RI SIPURI, Bimantech, Malang
} 
dibentuk untuk mengungkapkan kebenaran atas pelanggaran hak asasi manusia yang berat dan melaksanakan rekonsiliasi.

3. Menurut Undang-Undang No.27 Tahun 2004, yang dimaksud dengan amnesti adalah pengampunan yang diberikan oleh Presiden kepada pelaku pelanggaran hak asasi manusia yang berat dengan memperhatikan pertimbangan Dewan Perwakilan Rakyat. $^{2}$

C. Latar belakang dibatalkannya Undang-Undang Nomor 27 Tahun 2004 tentang Komisi Kebenaran dan Rekonsiliasi di Indonesia oleh Mahkamah Konstitusi

Pernyataan tersebut memang cukup beralasan, mengingat model KKR yang diusung dalam Undang-Undang tersebut belum mencerminkan KKR yang ideal dan independen. Sebagaimana model sesungguhnya yakni KKR di Afrika Selatan yang merupakan KKR yang meski masih memiliki sejumlah kekurangan tetapi dapat dikatakan sangat berhasil dalam pelaksanaannya.

Dikatakan belum ideal dikarenakan terdapat ketentuan-ketentuan dalam UU tersebut yang belum merepresentasikan suatu penghormatan HAM, serta secara sistem dan organisasi belum tepat. Diperinci sebagai berikut:

1. Pasal 1(9) Undang-Undang KKR menyatakan bahwa "amnesti adalah pengampunan yang diberikan oleh Presiden kepada pelaku pelanggaran HAM berat dengan memperhatikan pertimbangan Dewan Perwakilan Rakyat". Hal ini tentu sangat lucu mengingat bagaimana mungkin seorang yang telah melakukan pelanggaran HAM berat dapat begitu saja diampuni tanpa mendapatkan hukuman, bahkan meski korban tidak memaafkan sebagaimana terdapat dalam pasal 29 ayat (2).Apalagi pelanggaran HAM berat yang telah diselesaikan oleh komisi tidak dapat diajukan ke Pengadilan HAM ad hoc (Pasal 44). Lain halnya dengan pemberian amnesti oleh KKR di Afsel yang pada dasarnya dapat diberikan asal terdapat empat syarat yakni: (1) pengakuan oleh pelaku kejahatan HAM diberikan sejujurjujur dan selengkap-lengkapnya; (2) tindakan di masa lalu dalam mana ia terlibat, sepenuhnya merupakan tindakan yang dimotivasi oleh alasan politik, bukan dan tidak pernah dimotivasi oleh alasan pribadi; (3) tidak ada keuntungan 
pribadi dalam tindakan itu; dan (4) tindakan itu tidak berlebihan. Di luar itu, kesediaan untuk memaafkan pelaku oleh korban kerap menjadi pertimbangan lain untuk memberikan amnesti. Dari syarat diatas dapat dilihat bahwa pemberian amnesti oleh KKR di Afsel tidak mudah untuk didapatkan. Meskipun pelanggar HAM berat masih memiliki kemungkinan untuk lolos dari jeratan pengadilan dan itu merupakan kekurangan.

2. Dalam pasal 27 dinyatakan bahwa "Kompensasi dan rehabilitasi sebagaimana dimaksud dalam Pasal 19 dapat diberikan apabila permohonan amnesti dikabulkan". Yang berarti bahwa apabila permohonan amnesti ditolak maka kompensasi dan/atau rehabilitasi tidak diberikan oleh Negara, serta perkaranya ditindaklanjuti untuk diselesaikan berdasarkan ketentuan Undang-Undang Nomor 26 tahun 2000 tentang Pengadilan Hak Asasi Manusia". Patut dicatat pula bahwa dalam hal ini tidak ada jaminan bahwa Pengadilan HAM akan memproses kasus yang permohonan amnestinya telah ditolak. Oleh karena itu, tidak terdapat jaminan pula bahwa seorang korban pelanggaran HAM akan memperoleh kompensasi yang merupakan haknya.

3. KKR di Afrika Selatan, lebih menekankan aspek truth-telling (penceritaan kebenaran), bukan truth-seeking (pencarian kebenaran), dalam ruang lingkup dan mekanisme kerja mereka. Lain halnya KKR di Indonesia yang diarahkan sebagai komisi yang memiliki fungsi truth-seeking, hal itu sah saja. Konsekuensi dari pilihan itu adalah memberi wewenang luas kepada KKR untuk melakukan penyelidikan tentang peristiwa pelanggaran HAM. Akan tetapi, harus diingat, fungsi semacam ini akan tumpang tindih dengan fungsi Komisi Nasional (Komnas) HAM dan tak dapat dielakkan akan muncul pandangan bahwa KKR hanya akan menambah daftar komisi yang dibentuk, tetapi tidak pernah menghasilkan kerja maksimal. Hal inilah yang kemudian memunculkan opini bahwa KKR di Indonesia tidak memiliki kewenangan yang jelas sehingga menimbulkan ketidakpastian hukum dalam setiap putusannya. ${ }^{3}$

\footnotetext{
${ }^{3}$ Lihat,__ 2006, Pernyataan Tertulis ICTJ : Keabsahan Dari Komisi Kebenaran Dan Rekonsiliasi (ICTJ Written Submission:Legality Of Truth and Reconciliation Commission), ,pg 5-25
} 


\section{Kesimpulan}

Dari pemaparan diatas ada beberapa hal yang mungkin dapat dijadikan masukan, bahwa hendaknya KKR sebagai lembaga independent yang mengungkapkan kebenaran atas pelanggaran hak asasi manusia yang berat dan melaksanakan rekonsiliasi hendaknya memberikan rehabilitasi, restitusi, dan kompensasi lebih dulu dari pemberian amnesti, sebagai bentuk penghormatan atas HAM. Selain itu, tidak secara mutlak memberikan amnesti (jika telah memenuhi syarat yang disebut diatas), melainkan pengurangan hukuman diawali dengan proses peradilan yang dijadikan lanjutan setelah melalui proses di KKR atau dapat juga adanya suatu amnesti tetapi dengan seleksi yang ketat dan tidak berlaku untuk pelanggaran HAM berupa penyiksaan dan penghilangan nyawa agar KKR tidak bertentangan dengan instrumeninstrumen HAM. Perihal hal ini ada pernyataan menarik dari pengamat sospol DR. Daniel Sparinga, bahwa penghormatan atas hak asasi manusia sebagai dasar dari sebuah kehidupan yang bermartabat adalah sesuatu yang lebih bernilai daripada sekedar menghukum orang. ${ }^{4}$ Meskipun tanpa bermaksud mengesampingkan pernyataan beliau, tetapi penghormatan atas hak asasi manusia akan lebih bernilai lagi jika keadilan ikut ditegakkan.

\footnotetext{
${ }^{4}$ Daniel Sparinga, 2003, Komisi Kebenaran Dan Rekonsiliasi : Penyelesaian Atas warisan Rejim Otoritarian Dan Penyelematan Masa Depan Di Indonesia, disampaikan dalam Seminar Pembangunan Hukum Nasional VIII di Denpasar pada tanggal 14 - 18 Juli 2003, Badan Pembinaan Hukum Nasional Departemen Kehakiman dan Hak Asasi Manusia RI, pg 9
} 